\title{
Food consumption and metabolic control in children and adolescents with type 1 diabetes mellitus
}

\author{
Consumo alimentar e controle metabólico em crianças e adolescentes portadores de diabetes melito tipo 1 \\ Consumo alimentar y control metabólico en niños y adolescentes portadores de diabetes mellitus tipo 1
}

Sheylle Almeida S. Teles ${ }^{1}$, Nélida Schmid Fornés ${ }^{2}$

\section{ABSTRACT}

Objective: To evaluate the relationship between dietary intake and metabolic control in children and adolescents with type 1 diabetes mellitus (DM1).

Methods: Cross-sectional study with 11 children and 39 adolescents with DM1. The following variabes were collected: meals data (habits, three 24-hour recall - R24h), therapeutic (insulin) and biochemical data (index of glycated hemoglobin - in HbA, casual glucose - GLC, post-prandial glucose-GLPP, and lipid profile). Student's t-test and Pearson correlation were applied, being significant $p<0.05$.

Results: Among the studied subjects, consumption of food out of time was identified in $64 \%$ and consumption of sugary products in $6 \%$. The parameters included in the lipid profile were adequate in $88 \%$ for serum total cholesterol (sCT), in $92 \%$ for LDL, in $100 \%$ of children and $69 \%$ of adolescents for TG and in $82 \%$ of children and $84.6 \%$ of adolescents for HDL. InHbA was adequate in $64 \%$ and GLPP in $18 \%$ of the studied population. There was a negative correlation between sCT and carbohydrate intake $(\mathrm{r}=-0.324 ; p=0.022)$ and a positive correlation with lipids intake $(\mathrm{r}=0.315 ; p=0.026)$.

Conclusions: The increased consumption of lipids and the lower carbohydrate intake are correlated with higher levels of sCT.
Key-words: adolescent; food consumption; child; diabetes mellitus, type 1; dyslipidemias; blood glucose.

\section{RESUMO}

Objetivo: Avaliar a relação entre consumo alimentar e controle metabólico em crianças e adolescentes com diabetes melito tipo 1 (DM1).

Métodos: Estudo transversal com 11 crianças e 39 adolescentes com DM1. Coletaram-se dados alimentares (hábitos, três recordatórios de 24 horas - R24h), terapêuticos (insulinoterapia), bioquímicos (índice da hemoglobina glicada - inHbA, glicemias casuais - GLC, pós-prandiais - GLPP e perfil lipídico). Utilizou-se o teste $t$ de Student e a correlação de Pearson, sendo significante $p<0,05$.

Resultados: Dentre os indivíduos estudados, identificaram-se alimentação fora de horário em $64 \%$ e consumo de produtos açucarados em $6 \%$. Os parâmetros que compõem o perfil lipídico foram adequados em: colesterol total sérico - CTs (88\%), LDL (92\%), TG (100\% das crianças e $69 \%$ dos adolescentes) e HDL ( $82 \%$ das crianças e $85 \%$ dos adolescentes). Quanto aos parâmetros que medem o controle glicêmico, o inHbA foi adequado em $64 \%$ e a GLPP em $18 \%$. Houve correlação negativa entre CTs e consumo de carboidratos $(r=-0,324 ; p=0,022)$ e positiva com o consumo de lipídeos ( $\mathrm{r}=0,315 ; p=0,026)$.
Instituição: Ambulatório de Endocrinologia do Hospital das Clínicas da Universidade Federal de Goiás (UFG), Goiânia, GO, Brasil

${ }^{1}$ Mestre em Ciências da Saúde pela Faculdade de Medicina da UFG, Goiânia, GO, Brasil

${ }^{2}$ Pós-Doutora em Medicina Preventiva e Saúde Pública pela Universidad Autónoma de Madrid; Professora da Faculdade de Nutrição da UFG, Goiânia, GO, Brasil
Endereço para correspondência

Sheylle Almeida S. Teles

Rua Serra do Fogo, quadra 01, lote 09 - Conjunto Sonho Verde

CEP 74730-540 - Goiânia/GO

E-mail: sheyllealmeida@gmail.com

Fonte financiadora: Conselho Nacional de Desenvolvimento Científico e Tecnológico (CNPq) - bolsa de mestrado (processo 579392/2008-2)

Conflito de interesse: nada a declarar

Recebido em: 15/7/2010

Aprovado em: 14/12/2010 
Conclusões: O maior consumo de lipídeos e a consequente menor ingestão de carboidratos correlacionaram-se a maiores níveis de CTs.

Palavras-chave: adolescente; consumo de alimentos; criança; diabetes mellitus tipo 1; dislipidemias; glicemia.

\section{RESUMEN}

Objetivo: Evaluar la relación entre consumo alimentar y control metabólico en niños y adolescentes con diabetes mellitus tipo 1 (DM1).

Métodos: Estudio transversal con 11 niños y 39 adolescentes con DM1. Se recogieron datos alimentares (hábitos, tres recordatorios de 24 horas-R24h), terapéuticos (insulinoterapia), bioquímicos (índice de hemoglobina glucadainHbA, glucemias casuales - GLC, post-prandiales - GLPP y perfil lipídico). Se utilizó la Prueba t de Student y la correlación de Pearson, siendo significante $p<0,05$.

Resultados: Entre los individuos estudiados, se identificaron alimentación fuera de horario en $64 \%$ y consumo de productos azucarados en $6 \%$. Los parámetros que componen el perfil lipídico fueron adecuados en: colesterol total sérico - $\mathrm{CT}_{\mathrm{s}}-88 \%$, LDL - 92\%, TG - 100\% de los niños y $69,2 \%$ de los adolescentes y HDL - $81,8 \%$ de los niños y $84,6 \%$ de los adolescentes. Respecto a los parámetros que miden el control glucémico, el inHbA fue adecuado en $64 \%$ y la GLPP en $18 \%$. Hubo correlación negativa entre $\mathrm{CT}_{\mathrm{s}}$ y consumo de carbohidratos $(\mathrm{r}=-0,324 ; p=0,022)$ y positiva con lípidos ( $\mathrm{r}=0,315 ; p=0,026)$.

Conclusiones: El mayor consumo de lípidos y la consecuente menor ingestión de carbohidratos se correlacionan a mayores niveles de $\mathrm{CT}_{\mathrm{s}}$.

Palabras clave: adolescente; consumo de alimentos; niño; diabetes mellitus tipo 1; dislipidemias; glucemia.

\section{Introduction}

The number of diabetes mellitus (DM) cases worldwide was estimated at 171 million in 2000, and may reach 366 million by $2030^{(1)}$. A multicenter study conducted in Brazil in the 1980s found an overall (type 1 and 2) DM prevalence rate of $7.6 \%$ among the urban population aged 30 to $69^{(2)}$. No population-wide studies have been conducted in Brazil for the specific purpose of characterizing the epidemiology of type 1 diabetes mellitus (T1DM). The prevalence and incidence of this condition among under- $14 \mathrm{~s}$ in the country is estimated at 4 cases per 10.000 and 8 cases per 100.000 respectively ${ }^{(3)}$.

Dietary habits play an essential role in glycemic control (GC) in people living with T1DM. The results of the Diabetes Control and Complications Trial (DCCT) show that, among patients undergoing intensive glycemic control, consumption of low-carbohydrate, high-fat (particularly high-saturated fat) diets is associated with poorer GC, regardless of exercise and serum triglyceride levels ${ }^{(4)}$.

Dyslipidemia is a common finding in $\mathrm{T} 1 \mathrm{DM}^{(5)}$, possibly due to increased cholesterol absorption ${ }^{(6)}$. In patients who follow dietary recommendations, the relevance of metabolic control in the management of dyslipidemia goes beyond mere reductions in lipid intake. Targets for dietary management should ensure adequate intake of fiber and carbohydrates, which have an impact on glycated hemoglobin (A1c) levels and, consequently, on metabolic control ${ }^{(5)}$.

In light of the growing importance of T1DM in the current epidemiological scenario and of the influence of diet on the progression of diabetes, the present study sought to assess the relationship between dietary consumption and metabolic control in children and adolescents with T1DM.

\section{Method}

This was a cross-sectional study of children and adolescents with T1DM treated at the Hospital das Clínicas da Universidade Federal de Goiás (HC/UFG) outpatient Endocrinology Clinic. At the time of the study, 240 people with T1DM were registered as patients of the aforementioned clinic: 31 children (12\%), 79 adolescents (32.2\%) and 135 adults (55.8\%). The sample comprised 54 children and adolescents who agreed to take part in the study (49\% of all registered children and adolescents). Of these 54, four were excluded due to incomplete dietary intake data, leaving a final sample size of 50 .

For the purposes of this study, "child" was defined as any participant between the ages of 4 and 9, and "adolescent," as any participant between the ages of 10 and $18^{(7)}$. The criteria for inclusion were an established diagnosis of T1DM of at least five months' duration and current insulin therapy. The criteria for exclusion were a history of limb amputation and/ or a prior diagnosis of dyslipidemia, celiac disease, nephropathy, thyroid disease, or cardiovascular disease.

Chart reviews were used to determine which participants met the inclusion and exclusion criteria. Data were collected 
between January and August 2009, using a structured instrument designed to collect information on a) dietary habits: eating outside regular meal times and eating outside the home (including frequency and type of foods consumed); b) dietary intake assessment: three 24-hour dietary recalls ( $24 \mathrm{hR})$, one conducted on the day of the interview and the remaining two by telephone, each 30 days apart; c) laboratory tests: lipid profile (triglycerides, total serum cholesterol, high-dentisy lipoprotein [HDL], low-density lipoprotein [LDL], and very low-density lipoprotein [VLDL]), glycated hemoglobin $(\mathrm{A} 1 \mathrm{c})$, and random (RBS) and postprandial (PPBS) blood sugar measurements.

All three dietary recalls were entered into an especially designed spreadsheet containing nutrition facts compiled from several food composition tables ${ }^{(8-14)}$, enabling inclusion of regional foods and specialty (sugar-free and lowfat) products. Macronutrient intake was compared against Brazilian Diabetes Society ${ }^{(15)}$ guidelines for carbohydrates (50-60\% of total energy intake), fats ( $<30 \%$ of total energy intake) and protein (0.8-1.0g protein $/ \mathrm{kg} /$ day). American Diabetes Association recommendations ${ }^{(16)}$ were used for assessment of fiber and cholesterol intake $(14 \mathrm{~g} / 1000 \mathrm{kcal}$ and $<200 \mathrm{mg} /$ day respectively).

After determining the energy contribution of carbohydrates, fats, and protein, nutrients were then adjusted for total energy intake. This calculation was obtained from the residuals of linear regression models constructed with macronutrient calories as a dependent variable and total calorie intake as the independent variable. To avoid null or negative values, residuals were added so as to make the lowest sum $>0$. Adjustment for total energy intake by means of regression modeling is common practice in dietary epidemiology studies. One of the advantages of this method is that, in assessing the influence of consuming a certain food or nutrient on the occurrence of a disease, it negates the potential influence of the disease on total energy intake - which is usually associated with food or nutrient intake ${ }^{(17)}$.

The most recent lipid profile and $\mathrm{A} 1 \mathrm{c}$ measurements were obtained from patient charts. If a participant's most recent lipid profile was over 3 months old, a new test was ordered as part of routine outpatient follow-up. New A1c results were brought by participants at each appointment, and, therefore, were never more than 2 weeks old. RBS measurements were obtained at enrollment with an Accu-Chek ${ }^{\circledR}$ Advantage portable glucose meter.

Lipid profile assessment was based on American Academy of Pediatrics-recommended levels ${ }^{(18)}$. Due to the variety of methods used for measurement of A1c levels, we chose to use the index of measured A1c to the upper limit of normal for the method used (glycated hemoglobin : upper limit of normal), which was then classified as adequate or inadequate, as recommended by Chase $e t \mathrm{al}^{(19)}$ and later used by Cunha $e t$ $a l^{(20)}$, Gomes et $a l^{(21)}$ and Castro $e t a l^{(22)}$. For the purposes of the present study, an A1c $<1.33$ times the upper limit of normal was considered "adequate glycemic control," whereas A1c values $\geq 1.33$ times the upper limit of normal were regarded as evidence of inadequate glycemic control.

This study was approved by the HC/UFG Animal and Human Subject Research Ethics Committee. All participants and their legal guardians provided voluntary, written informed consent for inclusion in the study after all methods and procedures had been thoroughly explained.

Study data were compiled into a Microsoft ${ }^{\circledR}$ Excel 2003 spreadsheet and exported to the Statistical Package for the Social Sciences (SPSS) 17.0 software environment. Biochemical and dietary profile data were analyzed by means of simple descriptive statistics, with categorical variables expressed as absolute and relative frequencies and continuous variables as mean \pm standard deviation. The distribution of continuous variables was assessed by means of the Kolmogorov-Smirnov (K-S) test; variables with $p \geq 0.05$ were classified as having a normal distribution. The Student $t$ test was used for comparison of the adequate GC and inadequate GC groups. Pearson's correlation coefficient was used to assess potential correlations between dietary and biochemical variables. The significance level was set at $p<0.05$ for all tests.

\section{Results}

A total of 50 participants were assessed: 11 children (22\%) and 39 adolescents (78\%). Mean age was 7.1 \pm 1.7 years for children and $14.1 \pm 2.5$ years among adolescence. Mean time elapsed since initial diagnosis of T1DM was $5.4 \pm 4.3$ years (children, $2.4 \pm 1.6$ years; adolescents, $6.2 \pm 4.5$ years). The mean daily insulin dose was $0.77 \pm 0.27 \mathrm{U} / \mathrm{kg}$, with no significant difference between children and adolescents $(0.78 \pm 0.32 \mathrm{U} / \mathrm{kg}$ vs $0.77 \pm 0.26 \mathrm{U} / \mathrm{kg}$ respectively). The mean number of daily insulin shots was 1.7 in children and two in adolescents.

The meals skipped most often were the mid-morning snack $(28 \%)$ and the evening snack or supper (36\%). Adolescents skipped meals more often than children. Most participants $(64 \%)$ ate outside planned meal hours; the foods most often 
consumed during these unplanned snacks were fruit, breads, and similar goods (56\%). Products containing sugar were consumed by $6 \%$ of participants. Seventy percent of participants ate outside the home only rarely; when they did eat outside the home, participants usually ate large meals (18\%) (Table 1).

An analysis of the biochemical parameters measured in the sample is shown in Table 2. A1c (expressed as ratio of measured A1c to the upper limit of normal) was adequate in $64 \%$ of cases, and PPBS, in $18 \%$. Total cholesterol, LDL, triglycerides, and HDL were within normal limits in $88 \%$, $92 \%, 76 \%$, and $84 \%$ of participants respectively.

Dietary recalls (Table 3) showed no significant differences between the dietary habits of children and adolescents, although the former had a significantly higher protein intake per $\mathrm{kg}$ of body weight $(p=0.008)$. Likewise, there were no significant between-group differences when participants

Table 1 - Dietary habits of children $(n=11)$ and adolescents $(n=39)$ with T1DM

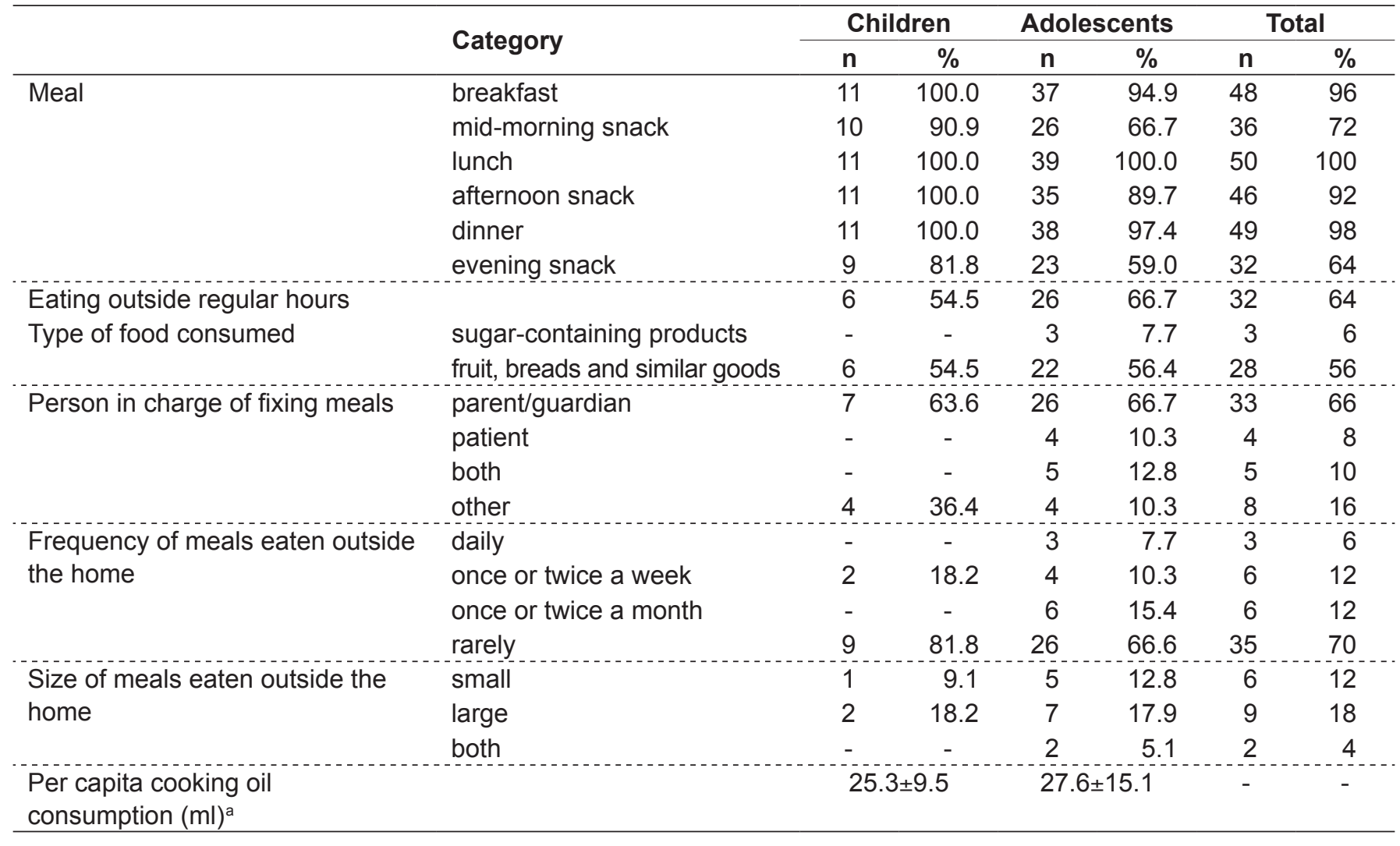

aMean \pm SD

Table 2 - Biochemical profile of children and adolescents with T1DM

\begin{tabular}{|c|c|c|c|c|c|c|}
\hline \multirow{2}{*}{ Variable } & \multirow{2}{*}{ Reference range } & \multicolumn{2}{|c|}{ Adequate } & \multicolumn{2}{|c|}{ Inadequate } & \multirow[t]{2}{*}{ Mean \pm SD } \\
\hline & & $\mathbf{n}$ & $\%$ & $\mathbf{n}$ & $\%$ & \\
\hline A1c ratio ${ }^{a}$ & $<1.33$ & 32 & 64.0 & 18 & 36.0 & $1.29 \pm 0.4$ \\
\hline $\operatorname{RBS}(\mathrm{mg} / \mathrm{dL})^{\mathrm{b}}$ & $<200$ & 19 & 38.0 & 31 & 62.0 & $268.3 \pm 133.9$ \\
\hline $\operatorname{PPBS}(\mathrm{mg} / \mathrm{dL})^{\mathrm{c}}$ & $<140$ & 9 & 18.0 & 41 & 82.0 & $253.2 \pm 120.1$ \\
\hline \multirow[t]{2}{*}{$\mathrm{TG}(\mathrm{mg} / \mathrm{dL})^{\mathrm{d}}$} & $\leq 100($ age $<10 y)$ & 11 & 100.0 & - & - & $68.8 \pm 17.5$ \\
\hline & $\leq 130($ age $10-19 y)$ & 27 & 69.2 & 12 & 30.8 & $98.1 \pm 46.1$ \\
\hline Total serum cholesterol (mg/dL) & $<200$ & 44 & 88.0 & 6 & 12.0 & $159.0 \pm 28.7$ \\
\hline \multirow[t]{2}{*}{$\mathrm{HDL}(\mathrm{mg} / \mathrm{dL})^{\mathrm{e}}$} & $\geq 40$ (age <10y) & 9 & 81.8 & 2 & 18.2 & $47.1 \pm 9.7$ \\
\hline & z35 (age 10-19y) & 33 & 84.6 & 6 & 15.4 & $48.9 \pm 11.5$ \\
\hline $\operatorname{LDL}(\mathrm{mg} / \mathrm{dL})^{\mathrm{f}}$ & $<130$ & 46 & 92.0 & 4 & 8.0 & $92.6 \pm 24.9$ \\
\hline
\end{tabular}

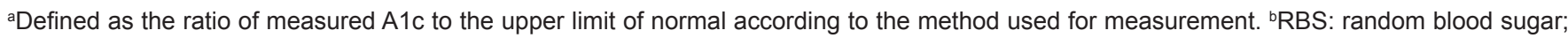
'PPBS: postprandial blood sugar; ${ }^{\mathrm{d} T G}$ : triglycerides; eHDL: high-density lipoprotein; ' $L D L$ : Iow-density lipoprotein. 
Table 3 - Dietary variables, according to age range and glycemic control (GC), in children and adolescents with T1DM. All values expressed as mean \pm SD

\begin{tabular}{|c|c|c|c|c|c|c|}
\hline Dietary variable & $\begin{array}{c}\text { Children } \\
(n=11)\end{array}$ & $\begin{array}{c}\text { Adolescents } \\
(n=39)\end{array}$ & $p^{*}$ & $\begin{array}{c}\text { Adequate GC } \\
(n=32)\end{array}$ & $\begin{array}{c}\text { Inadequate GC } \\
(n=18)\end{array}$ & $p^{*}$ \\
\hline TEI (kcal) ${ }^{a}$ & $1455.9 \pm 364.6$ & $1790.8 \pm 579.7$ & 0.077 & $1656.3 \pm 658.2$ & $1655.8 \pm 434.0$ & 0.998 \\
\hline$\% \mathrm{CHO}^{\mathrm{b}}$ & $46.3 \pm 4.8$ & $45.1 \pm 7.1$ & 0.605 & $44.7 \pm 8.0$ & $44.8 \pm 5.0$ & 0.957 \\
\hline$\% \mathrm{FAT}^{\mathrm{c}}$ & $37.6 \pm 5.4$ & $38.6 \pm 7.7$ & 0.697 & $39.0 \pm 8.5$ & $40.0 \pm 7.0$ & 0.651 \\
\hline$\% \mathrm{PTN}^{\mathrm{d}}$ & $16.1 \pm 2.4$ & $16.3 \pm 3.2$ & 0.839 & $16.4 \pm 2.9$ & $15.2 \pm 3.4$ & 0.206 \\
\hline $\mathrm{gPtn} / \mathrm{kg} / \mathrm{day}^{\mathrm{e}}$ & $2.5 \pm 0.9$ & $1.6 \pm 0.7$ & 0.008 & $1.8 \pm 0.8$ & $1.4 \pm 0.9$ & 0.085 \\
\hline SAT $(m g)^{f}$ & $14.1 \pm 5.7$ & $16.2 \pm 8.0$ & 0.419 & $15.2 \pm 8.3$ & $15.7 \pm 6.8$ & 0.833 \\
\hline UNSAT $(\mathrm{mg})^{\mathrm{g}}$ & $17.5 \pm 8.2$ & $24.8 \pm 16.1$ & 0.156 & $22.5 \pm 15.9$ & $23.2 \pm 14.3$ & 0.874 \\
\hline $\mathrm{TC}(\mathrm{mg})^{\mathrm{h}}$ & $149.5 \pm 85.5$ & $201.0 \pm 101.9$ & 0.133 & $192.2 \pm 117.3$ & $161.0 \pm 60.4$ & 0.202 \\
\hline TF $(g)^{i}$ & $23.6 \pm 7.8$ & $27.9 \pm 14.0$ & 0.326 & $27.0 \pm 14.0$ & $22.7 \pm 12.8$ & 0.272 \\
\hline
\end{tabular}

${ }^{a}$ TEI: total energy intake (24-hour dietary recall); $\%$ CHO: percentage of TEI provided by carbohydrates; c\%LIP: percentage of TEI provided by fats; d\%PTN: percentage of TEI provided by protein; ' $\mathrm{gPtn} / \mathrm{kg} / \mathrm{day}$ : daily protein intake per $\mathrm{kg}$ of body weight; 'SAT: saturated fats; "9UNSAT: unsaturated fats; ${ }^{\text {TTC: }}$ total cholesterol intake; iTF: total fiber intake; iStudent $t$ test. ${ }^{*} p<0.05$.

Table 4 - Correlation $(r)$ between biochemical parameters and dietary habits in children and adolescents with T1DM

\begin{tabular}{|c|c|c|c|c|c|c|c|c|c|c|}
\hline & \multicolumn{2}{|c|}{ A1c ratio' } & \multicolumn{2}{|c|}{ PPBS $^{m}$} & \multicolumn{2}{|c|}{ Total cholesterol } & \multicolumn{2}{|c|}{ LDL $^{n}$} & \multicolumn{2}{|c|}{ TG० } \\
\hline & $\mathrm{r}^{\mathrm{a}}$ & $p$ & $\mathbf{r}^{\mathbf{a}}$ & $p$ & $\mathbf{r}^{\mathbf{a}}$ & $p$ & $\mathbf{r}^{\mathbf{a}}$ & $p$ & $\mathbf{r}^{\mathbf{a}}$ & $p$ \\
\hline $\mathrm{CHO}(\mathrm{g})^{b}$ & 0.000 & 0.999 & 0.100 & 0.490 & -0.198 & 0.169 & -0.139 & 0.640 & -0.068 & 0.640 \\
\hline FAT $(g)^{c}$ & 0.040 & 0.782 & 0.275 & 0.053 & 0.078 & 0.592 & 0.092 & 0.666 & 0.063 & 0.666 \\
\hline $\operatorname{PTN}(g)^{d}$ & -0.008 & 0.956 & 0.168 & 0.243 & -0.105 & 0.468 & -0.057 & 0.418 & -0.117 & 0.418 \\
\hline $\mathrm{CHO}_{\text {adj }} \mathrm{e}$ & -0.039 & 0.790 & -0.217 & 0.130 & -0.324 & $0.022^{*}$ & -0.274 & 0.429 & -0.114 & 0.429 \\
\hline $\mathrm{FAT}_{\mathrm{adj}}^{\mathrm{adj}}$ & 0.055 & 0.707 & 0.200 & 0.163 & 0.315 & $0.026^{*}$ & 0.263 & 0.197 & 0.186 & 0.197 \\
\hline PTN $_{\text {adj }}^{\text {ad }} g$ & -0.051 & 0.728 & -0.030 & 0.835 & -0.092 & 0.526 & -0.069 & 0.147 & -0.208 & 0.147 \\
\hline SAT $(\mathrm{mg})^{\mathrm{h}}$ & -0.024 & 0.867 & 0.223 & 0.119 & 0.016 & 0.911 & 0.086 & 0.474 & -0.104 & 0.474 \\
\hline UNSAT $(\mathrm{mg})^{\mathrm{i}}$ & -0.021 & 0.883 & 0.260 & 0.069 & 0.003 & 0.983 & 0.071 & 0.666 & -0.063 & 0.666 \\
\hline $\mathrm{TC}(\mathrm{mg})^{\mathrm{i}}$ & -0.084 & 0.562 & 0.119 & 0.409 & -0.111 & 0.443 & -0.052 & 0.367 & -0.130 & 0.367 \\
\hline $\operatorname{TF}(g)^{\mathrm{k}}$ & -0.043 & 0.769 & 0.154 & 0.286 & -0.161 & 0.264 & -0.075 & 0.417 & -0.117 & 0.417 \\
\hline
\end{tabular}

ar: Pearson's correlation coefficient; ${ }^{b} \mathrm{CHO}(\mathrm{g})$ : mean carbohydrate intake; ${ }^{\mathrm{F}} \mathrm{FT}(\mathrm{g})$ : mean fat intake; ${ }^{\mathrm{d} P T N}(\mathrm{~g})$ : mean protein intake; ${ }^{\mathrm{C}} \mathrm{CHO}{ }_{\text {adi: }}$ carbohydrate intake adjusted for total energy intake; ${ }^{f} F A T_{\text {ad: }}$; fat intake adjusted for total energy intake; SPTN $_{\text {adi }}$ : protein intake adjusted for total energy intake; " $S A T(\mathrm{mg})$ : saturated fat intake; 'UNSAT (mg): unsaturated fat intake; ITC (mg): total cholesterol intake; ${ }^{\mathrm{TTF}}(\mathrm{g})$ : total fiber intake; 'A1c: ratio of measured A1c to the upper limit of normal according to the method used for measurement; ${ }^{2} P P B S$ : postprandial blood sugar; "LDL: low-density lipoprotein; ${ }^{\mathrm{P} T G}$ : triglycerides; ${ }^{*} p<0.05$.

were stratified by adequacy of GC. Carbohydrate intake was uniformly below recommended levels (50-60\% of total energy intake from carbohydrates), regardless of GC. Dietary fat consumption also exceeded recommended levels $(<30 \%$ of total energy intake), as did protein intake, particularly in children, whose mean daily protein intake $(2.5 \mathrm{~g} / \mathrm{kg} /$ day $)$ was more than twice as high as the RDI $(0.8-1.0 \mathrm{~g} / \mathrm{kg} /$ day $)$.

Analysis of potential correlations between dietary and biochemical variables (Table 4) showed no significant association between A1c level and nutrient intake. PPBS levels also were not correlated with nutrient intake, although a borderline-significant association was found between PPBS and absolute fat intake $(\mathrm{r}=0.275 ; p=0.053)$. After adjusting for total energy intake, a negative correlation was found between serum cholesterol levels and carbohydrate intake $(\mathrm{r}=-0.324 ; p=0.022)$, and a positive correlation between cholesterol levels and dietary fat consumption $(r=0.315$; $p=0.026$ ).

\section{Discussion}

The participants of this study were found to consume a low-carbohydrate, high-fat, high-protein diet. Carbohydrate and fat intake was similar to that reported in the DCCT, in which these nutrients accounted for $45.5 \%$ and $36.8 \%$ of total energy intake respectively ${ }^{(4)}$. Despite the risk of highfat diets in the setting of T1DM, several studies ${ }^{(23-25)}$ have found that the dietary habits of people with type 1 diabetes 
are often characterized by excess fat intake. On the other hand, total dietary fiber and cholesterol intake was within ADA-recommended levels $(14 \mathrm{~g} / 1000 \mathrm{kcal}$ and $<200 \mathrm{mg}$ respectively $)^{(16)}$, which should afford some protection against cardiovascular disease.

There was no significant association between fat intake and A1c levels, perhaps due to small sample size. The negative correlation between A1c levels and carbohydrate intake provides evidence of the protective effect of the latter when consumed in lieu of dietary fats ${ }^{(5)}$. A significant association between triglyceride levels and percent energy intake provided by carbohydrates has been reported elsewhere in the literature ${ }^{(5)}$, but no such association was found in our sample.

The present study showed that higher fat intake and the consequently lower energy intake provided by carbohydrates are associated with increased serum cholesterol levels. Likewise, the DCCT reported an association between replacement of carbohydrates with fat in the diet and increased A1c levels ${ }^{(4)}$, confirming the adverse impact of fat intake on GC.

Regarding biochemical parameters, lipid profile adequacy was associated with that of current and past markers of glycemic control. Compared to controls, participants with T1DM and adequate GC had similar LDL and total cholesterol levels, lower triglycerides and higher HDL concentrations. Subjects with ineffective GC exhibited an atherogenic lipid profile, with significantly higher LDL and total cholesterol levels and, contrary to expectations, higher HDL levels than in controls. In short, abnormal lipid profiles were uniformly present in our young subjects with T1DM, even in those who were newly diagnosed and those with adequate GC. The extent of these changes is, of course, greater in patients with poor $\mathrm{GC}^{(26)}$.

The inadequacy of PPBS levels in $82 \%$ of participants is an alarming finding in light of the evidence that postprandial hyperglycemia is directly associated with increased cardiovascular mortality. This impact is due to the oxidative stress and endothelial inflammation that accompany postprandial hyperglycemia with increased free fatty acids levels, triggering atherosclerosis ${ }^{(27)}$.

The postprandial and random blood sugar measurements obtained in our sample are in direct contradiction to its A1c patterns. Although $64 \%$ of participants had adequate A1c levels, rates of RBS and PPBS inadequacy were inordinately high (62\% and $82 \%$ respectively). One potential explanation for this finding is the fact that $\mathrm{A} 1 \mathrm{c}$ reflects the weighted average of mean daily blood glucose levels over a 3- to 4-month period, although it is most influenced by recent blood sugar levels ${ }^{(28)}$. Conversely, RBS and PPBS measurements (obtained at any time of day and 2 hours after meals respectively) reflect isolated events.

Factors that may have influenced RBS and PPBS measurements include: a) measurements were obtained during followup visits, and it is well known that patients are usually anxious and concerned during physician appointments ${ }^{(29)}$ particularly when their glycemic control is to be discussed; $b$ ) as patients are seen on a first-come-first-serve basis at the clinic where the present study was carried out and the clinic opens at noon, many patients — even those referred from other municipalities for treatment—often arrive before 11 a.m. Therefore, many patients eat an early lunch, skip lunch altogether, or eat unusual foods (particularly fast foods and junk foods sold near the hospital) on the day of their appointment, without changing their insulin administration schedule and dosage accordingly. These factors can have an adverse effect on the accuracy of random blood sugar measurements, making these readings reflect a deviation from patients' usual dietary habits.

Another potential influence on RBS and PPBS measurements is inadequate compliance with insulin administration schedules, particularly with regard to time. Conventional insulin therapy requires strict adherence to the planned timing and size of meals ${ }^{(29)}$. During their interviews, many participants informally reported frequent noncompliance with planned insulin administration schedules. This suggests that many of our subjects exhibit chronic postprandial hyperglycemia, though mild enough to have no major effect on A1c levels.

GC is an essential goal in the management of T1DM. Elevated A1c levels are associated with increased serum lipid concentrations and, consequently, with increased cardiovascular risk (CVR). Proportionally, a single percentage point increase in $\mathrm{A} 1 \mathrm{c}$ have been associated with a $7.8-\mathrm{mg} / \mathrm{dL}$ increase in total serum cholesterol and a $5.1-\mathrm{mg} / \mathrm{dL}$ increase in LDL concentrations in a study of children and adolescents with $\mathrm{T}_{1} \mathrm{DM}^{(30)}$.

Sample size was a limitation in this study. Nevertheless, bearing in mind the relatively low prevalence of T1DM and the high frequency of complications, we believe the number of participants was satisfactory. In Brazil, patients with T1DM are usually referred to specialty Unified Health System clinics for management, and the HC/UFG Department of Endocrinology is one of the most active such centers in the state of Goiás, with the highest outpatient flow and acceptance rates in the state. Therefore, the large number of individuals seen at this clinic enabled enrollment of a substantial sample of healthy (complication-free) volunteers living with T1DM. 
In short, dietary fat intake was correlated with total serum cholesterol levels in the study sample, highlighting the association between diet and metabolic control. Macronutrient intake was uniformly inadequate, which reflects a need for providing improved dietary guidance to this patient population. Dietary intervention is an effective means of improving blood glucose levels and lipid profile and, consequently, reducing CVR in people with T1DM. Nutritional guidance in this population should stress the importance of a balanced, varied diet designed to meet current dietary recommendations. This is especially relevant in light of the importance of controlled dietary fat intake as a strategy for prevention of dyslipidemia.

\section{Acknowledgements}

The authors would like to thank Professors Maria Luiza Ferreira Stringhini and Rosana de Moraes Borges Marques for their valuable support.

\section{References}

1. Wild S, Roglic G, Green A, Sicree R, King H. Global prevalence of diabetes: estimates for the year 2000 and projections for 2030. Diabetes Care 2004;27:1047-53.

2. Malerbi DA, Franco LJ. Multicenter study of the prevalence of diabetes mellitus and impaired glucose tolerance in the urban Brazilian population aged 30-69 yr. Diabetes Care 1992;15:1509-16.

3. Collado-Mesa F, Barceló A, Arheart KL, Messiah SE. An ecological analysis of childhood-onset type 1 diabetes incidence and prevalence in Latin America. Rev Panam Salud Publica 2004;15:388-94.

4. Delahanty LM, Nathan DM, Lachin JM, Hu FB, Cleary PA, Ziegler GK et al. Association of diet with glycated hemoglobin during intensive treatment of type 1 diabetes in the Diabetes Control and Complications Trial. Am J Clin Nutr 2009;89:518-24.

5. Wiltshire EJ, Hirte C, Couper JJ. Dietary fats do not contribute to hyperlipidemia in children and adolescents with type 1 diabetes. Diabetes Care 2003;26: 1356-61.

6. Gylling $\mathrm{H}$, Tuominen JA, Koivisto VA, Miettinen TA. Cholesterol metabolism in type 1 diabetes. Diabetes 2004;53:2217-22.

7. Organização Pan-Americana de Saúde. La salud del adolescente y el joven en las Américas. Washington DC: OPAS; 1985.

8. Franco G. Tabela de composição química dos alimentos. São Paulo: Atheneu; 2003

9. Ministério do Planejamento e Orçamento. Fundação Instituto Brasileiro de Geografia e Estatística - IBGE. Estudo nacional da despesa familiar - Endef. Tabelas de composição de alimentos. Rio de Janeiro: IBGE; 1996.

10. Naves MM, Silva MR, Silva MS, Oliveira AG. Culinária goiana-valor nutritivo de pratos tradicionais. Goiânia: Kelps; 2004.

11. Núcleo de Estudos e Pesquisas em Alimentação (NEPA). TACO - Tabela Brasileira de Composição de Alimentos. Campinas: Nepa-Unicamp; 2006.

12. Philippi ST. Tabela de composição de alimentos: suporte para decisão nutricional. Brasília: Anvisa, Finatec, NUT-UnB; 2001.

13. Pinheiro AB, Lacerda EM, Benzecry EH, Gomes MC, Costa VM. Tabela para avaliação de consumo alimentar em medidas caseiras. São Paulo: Atheneu; 2002.

14. Universidade de São Paulo. Faculdade de Ciências Farmacêuticas. Departamento de Alimentos e Nutrição Experimental/Brasilfoods [homepage on the Internet]. Tabela brasileira de composição de alimentos-USP versão 5.0.; 1998 [cited 2010 mai 10]. Available from: http://www.fcf.usp.br/tabela

15. Sociedade Brasileira de Diabetes. Diagnóstico e classificação do diabetes melito e tratamento do diabetes melito do tipo 2. Rio de Janeiro: Diagraphic Editora; 2002.

16. American Diabetes Association. Nutrition recommendations and interventions for diabetes: a position statement of the American Diabetes Association. Diabetes Care 2008;31 (Suppl 1):S61-78.
17. Willett WC. Implications of total energy intake for Epidemilogy analyses. In: Willett WC. Nutritional epidemiology. New York: Oxford University Press; 1998.

18. American Academy of Pediatrics. National Cholesterol Education Program: Report of the Expert Panel on Blood Cholesterol Levels in Children and Adolescents. Pediatrics 1992;89:525-84.

19. Chase HP, Jackson WE, Hoops SL, Cockerman RS, Archer PG, O'Brien D Glucose control and the renal and retinal complications of insulin-dependent diabetes. JAMA 1989;261:1155-60.

20. Cunha EF, Silva Jr GR, Clemente EL, Gomes MB. Crescimento de crianças diabéticas em controle ambulatorial em hospital universitário. Arq Bras Endocrinol Metab 1999;43:344-50.

21. Gomes MB, Fernandes LM, Fuks AG, Pontes CR, Castro SH, Affonso FS et al. Variabilidade do controle glicêmico de pacientes com diabetes tipo 1 e tipo 2 durante um ano de acompanhamento. Arq Bras Endocrinol Metab 2001;45:141-7.

22. Castro SH, Castro-Faria-Neto HC, Clemente EL, Gomes MB. Avaliação da suscetibilidade do LDL de pacientes com diabetes mellitus tipo 1 à oxidação in vitro e sua relação com o controle glicêmico. Arq Bras Endocrinol Metab 2004;48:513-7.

23. Helgeson VS, Viccaro L, Becker D, Escobar O, Siminerio L. Diet of adolescents with and without diabetes: Trading candy for potato chips? Diabetes Care 2006;29:982-7.

24. Toeller M, Buyken AE, Heitkamp G, Cathelineau G, Ferriss B, Michel G. Nutrient intakes as predictors of body weight in European people with type 1 diabetes. Int J Obes Relat Metab Disord 2001;25:1815-22.

25. Wolever TM, Hamad S, Chiasson JL, Josse RG, Leiter LA, Rodger NW et al. Day-to-day consistency in amount and source of carbohydrate intake associated with improved blood glucose control in type 1 diabetes. J Am Coll Nutr 1999;18:242-7.

26. Guy J, Ogden L, Wadwa RP, Hamman RF, Mayer-Davis EJ, Liese AD et al. Lipid and lipoprotein profiles in youth with and without type 1 diabetes: the SEARCH for Diabetes in Youth case-control study. Diabetes Care 2009;32:416-20.

27. Strojek K, Majkowska L, Zozulińska D, Gumprecht J, Krzymień J, Małecki M; Task Force for Postprandial Glycemia. Postprandial glycemia-review of current pathophysiological, epidemiological and clinical aspects. Pol Arch Med Wewn 2007;117:252-9.

28. Pimazoni-Netto A, Andriolo A, Fraige-Filho F, Tambascia M, Gomes MB, Melo $\mathrm{M}$ et al. Atualização sobre hemoglobina glicada ( $\mathrm{HbA1C}$ ) para avaliação do controle glicêmico e para o diagnóstico do diabetes: aspectos clínicos e laboratoriais. J Bras Patol Med Lab 2009;45:31-48.

29. American Diabetes Association. Position statement: standards of medica care in diabetes - 2010. Diabetes Care 2010;33 (Suppl. 1):S11-S61.

30. Petitti DB, Imperatore G, Palla SL, Daniels SR, Dolan LM, Kershnar AK et al. Serum lipids and glucose control: the SEARCH for Diabetes in Youth study. Arch Pediatr Adolesc Med 2007;161:159-65. 